\title{
Restrictions on the export of medical products hamper efforts to contain coronavirus disease (COVID-19) in Latin America and the Caribbean
}

\section{Summary}

Latin America and the Caribbean is highly dependent on imports of medical products, as less than $4 \%$ of these are sourced within the region itself. To date, more than 70 countries -including four of the region's top five suppliers, of which the first is the United States - have restricted their medical exports in response to COVID-19. Export restrictions are hampering the supply of products essential for fighting the pandemic in the region. Latin America and the Caribbean should make it a strategic objective to strengthen its productive capabilities in the pharmaceutical and medical supplies and equipment industries, in order to gain a less vulnerable footing to face health crises in the future. This will require the combined efforts of the public sector, business and academia in a mission-oriented industrial policy framework. Several of the region's countries have made worthwhile efforts in that direction, which must be sustained beyond the current pandemic.

\section{Introduction}

In less than four months, COVID-19 has spread virtually across the globe. According to the World Health Organization (WHO), as of 4 May 2020, the number of confirmed cases exceeded 3.4 million, across 215 countries, regions and territories. These include the 33 countries of Latin America and the Caribbean, where 248,672 confirmed cases were reported at that time. ${ }^{1}$ A prerequisite for adequately addressing this pandemic is to ensure that sufficient medical and health products are available when needed in all affected countries. This category includes medicines, medical supplies, test kits, mechanical ventilators, masks and other personal protective equipment for the general population and especially for the health professionals most exposed to the virus

The production of medicines and other medical and health supplies is highly concentrated in industrialized countries and a small number of developing countries, mainly in Asia. International trade thus plays a crucial role in ensuring their availability across regions and countries, especially developing ones, which today urgently need them but lack sufficient productive capabilities of their own, at least in the short term. Since March, however, export restrictions on medical and health products have proliferated, including by some of the world's leading suppliers. This note offers some elements to gauge the likely impact of these measures on the capacity of countries in the region to respond adequately to the COVID-19 pandemic.

See World Health Organization (WHO), "Coronavirus disease 2019 (COVID-19). Situation Report - 105" [online] https://www.who.int/docs/default-source/coronaviruse/situation-reports/20200504-covid-19-sitrep-105. pdf?sfvrsn=4cdda8af_2

\section{Summary}

\section{Introduction}

A. Latin America and the Caribbean in the global medical products trade

$B$. The proliferation of export restrictions and their implications for the region

C. Conclusions and preliminary recommendations

Annex
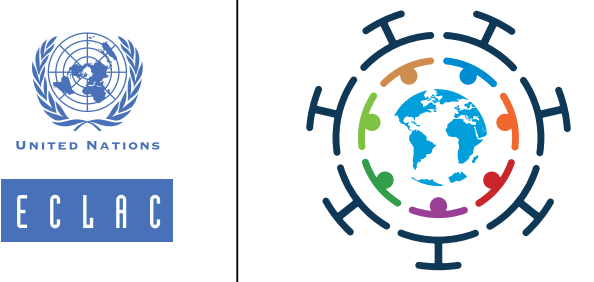


\section{A. Latin America and the Caribbean in the global medical products trade}

In 2018, the 20 countries of the region for which information is available together exported about US\$17.5 billion in products considered essential for combatting COVID-19, while

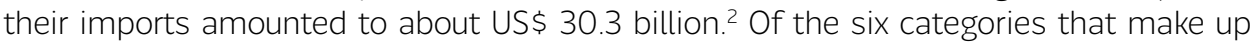
this product group, the region recorded surpluses only in medical consumables and other medical devices (see table 1 ).

Table 1

Latin America and the Caribbean (20 countries $\left.^{a}\right)$ : trade in medical products essential for combating COVID-19, 2018

(Millions of dollars and percentages)

\begin{tabular}{|l|c|c|c|r|r|}
\hline Category & Exports & Percentages & Imports & Percentages & Balance \\
\hline Test kits and apparatus & 658 & 3.8 & 10754 & 20.2 & -10096 \\
\hline Personal protective equipment & 924 & 5.3 & 2049 & 8.3 & -1125 \\
\hline Thermometers & 134 & 0.8 & 162 & 0.6 & -28 \\
\hline Disinfectants and sterilization products & 5307 & 30.4 & 10910 & 45.4 & -5603 \\
\hline Other medical devices & 5526 & 31.7 & 3988 & 16.0 & 1539 \\
\hline Medical consumables & 4897 & 28.1 & 2420 & 9.5 & 2477 \\
\hline Total & 17445 & 100.0 & 30282 & 100.0 & -12836 \\
\hline
\end{tabular}

Source: Economic Commission for Latin America and the Caribbean (ECLAC), on the basis of UN ComtradeInternational Trade Statistics Database.

a Antigua and Barbuda, Argentina, Barbados, Belize, Brazil, Chile, Colombia, Costa Rica, Dominican Republic, Ecuador, El Salvador, Guyana, Mexico, Nicaragua, Paraguay, Peru, Plurinational State of Bolivia, Saint Vincent and the Grenadines, Suriname and Uruguay.

Exports from the region are highly concentrated by origin. Mexico and Costa Rica exported more than three quarters of the total in 2018 (see figure 1A), which is explained largely by their involvement in international networks that produce medical devices and supplies. A similar situation arises in the Dominican Republic. In all three cases, this phenomenon is closely associated with multinational companies with a presence in those countries, producing mainly for the United States market. Conversely, the region's imports are more diversified (see figure 1B). Almost all the countries in the region run a trade deficit in medical products (see figure 2). Only Mexico and Costa Rica recorded significant surpluses in 2018, while the largest deficits occurred in South America.

The United States is the region's main supplier of products essential for combating COVID-19 and was the source of almost a third of total imports in 2018. It is followed by the European Union, with just over a quarter of the total, China (8\%, mainly personal protective equipment) and Switzerland (6\%, mainly highly sophisticated drugs and medical devices). Less than $4 \%$ of regional purchases come from the region itself (see figure 3).

See list in World Customs Organization (WCO), "HS classification reference for Covid-19 medical supplies 2nd Edition" [online] http://www.wcoomd.org/-/media/wco/public/global/pdf/topics/nomenclature/covid_19/ hs-classification-reference_en.pdf?la=en. 
Figure 1

Latin America and the Caribbean (20 countries $\left.^{\mathrm{a}}\right)$ : distribution of exports and imports of medical products essential for combating COVID-19, 2018

(Percentages)

\section{A. Exports}

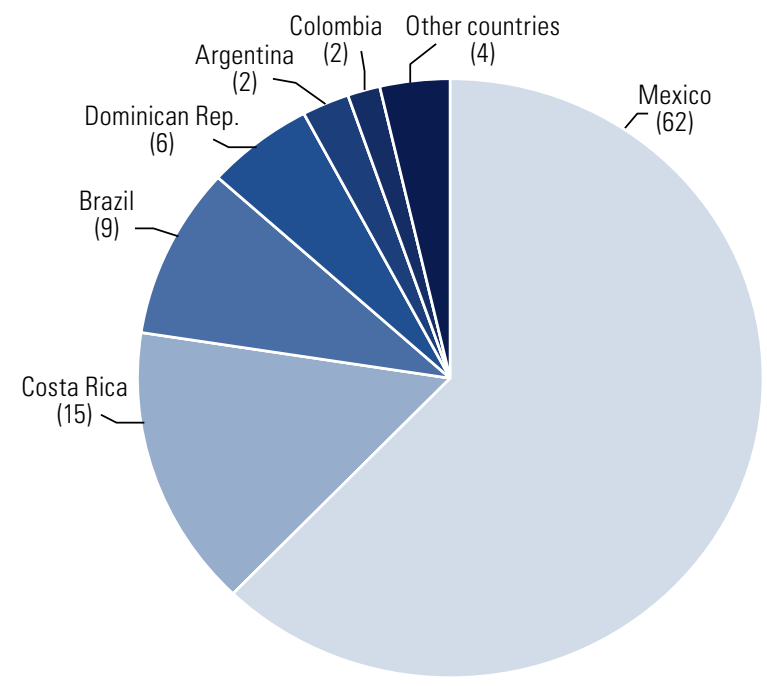

\section{B. Imports}

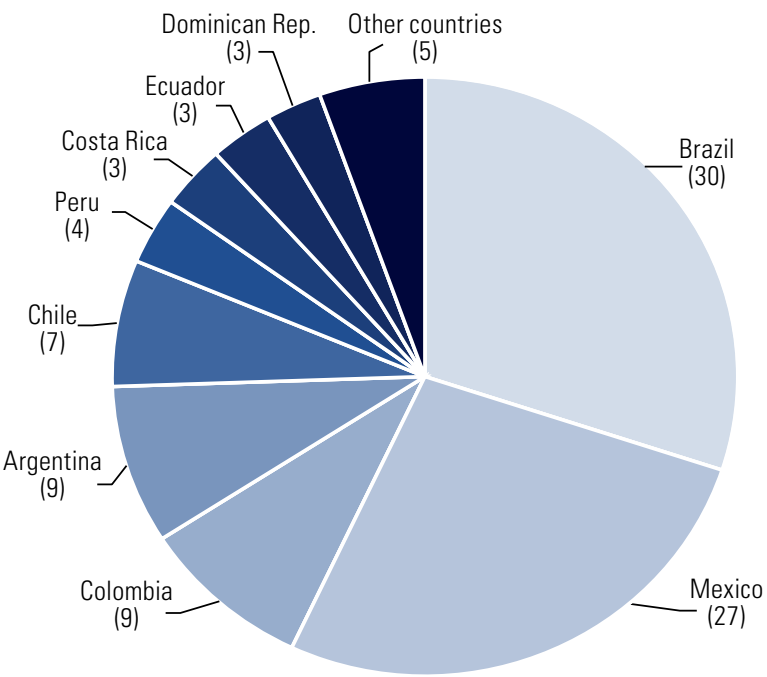

Source: Economic Commission for Latin America and the Caribbean (ECLAC), on the basis of UN Comtrade-International Trade Statistics Database.

a Antigua and Barbuda, Argentina, Barbados, Belize, Brazil, Chile, Colombia, Costa Rica, Dominican Republic, Ecuador, El Salvador, Guyana, Mexico, Nicaragua, Paraguay, Peru, Plurinational State of Bolivia, Saint Vincent and the Grenadines, Suriname and Uruguay.

Figure 2

Latin America and the Caribbean (26 countries): trade balance in medical products essential for combating COVID-19, 2018

(Billions of dollars)

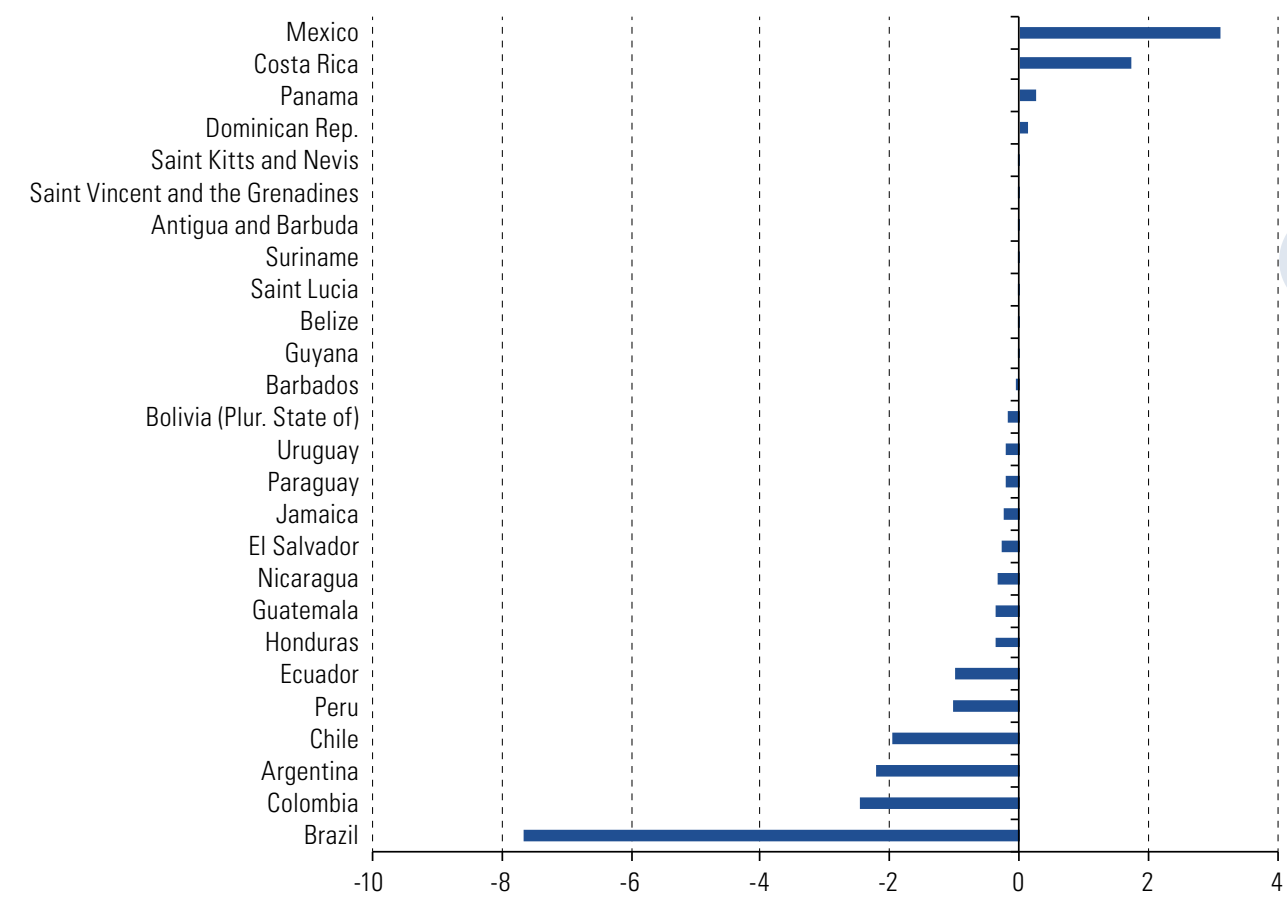

Source: Economic Commission for Latin America and the Caribbean (ECLAC), on the basis of UN Comtrade-International Trade Statistics Database.

${ }^{a}$ Data for Guatemala, Honduras, Jamaica, Saint Kitts and Nevis and Saint Lucia refer to 2017 and those for Panama refer to 2016. 
Figure 3

Latin America and the Caribbean (20 countries $^{\mathrm{a}}$ ): distribution by origin of imports of products essential for combating COVID-19, 2018

(Percentages)

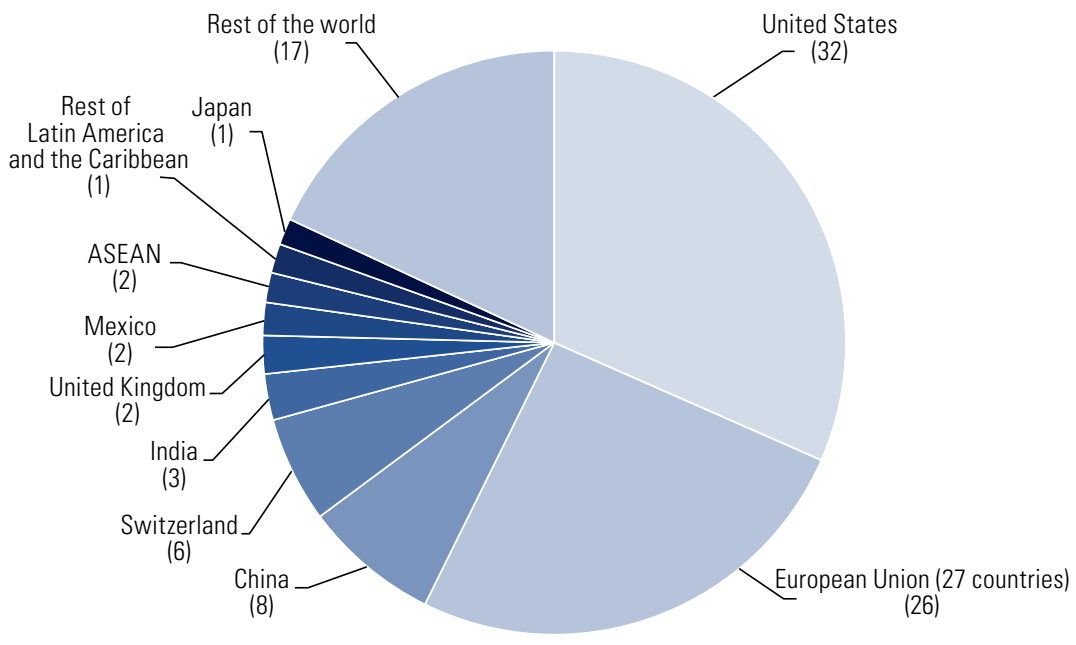

Source: Economic Commission for Latin America and the Caribbean (ECLAC), on the basis of UN ComtradeInternational Trade Statistics Database.

Note: ASEAN - Association of Southeast Asian Nations.

a Antigua and Barbuda, Argentina, Barbados, Belize, Brazil, Chile, Colombia, Costa Rica, Dominican Republic, Ecuador, El Salvador, Guyana, Mexico, Nicaragua, Paraguay, Peru, Plurinational State of Bolivia, Saint Vincent and the Grenadines, Suriname and Uruguay.

\section{B. The proliferation of export restrictions and their implications for the region}

Especially since March 2020, several countries have imposed export restrictions on medical products in response to COVID-19. At the beginning of May, over 70 countries had taken such measures. Table 2 shows the measures taken by the main suppliers of Latin America and the Caribbean, as well as by some countries within the region. These measures vary in three respects:

(i) Type of restriction: in some cases exports are banned altogether, while in other cases a permit is required for export.

(ii) Scope: in some cases the restriction applies to specific products and in others to extensive listings.

(iii) Duration: some restrictions have a set application period, while others are indefinite.

The list of countries that are applying export restrictions on medical products includes four of the five major suppliers in the region. However, the measures taken by each country involve different levels of risk to the regional supply. In general, the measures adopted by the European Union and Switzerland may be considered relatively low-risk for two reasons: firstly, they apply only to personal protective equipment (masks, gloves, visors, gowns, and so on), for which the region's main suppliers are China, other Asian countries and the United States; ${ }^{3}$ and, secondly, both the European Union and Switzerland have established a requirement to obtain a permit to export outside Europe, not a ban on doing so. 
Table 2

Selected countries and groupings: restrictions on the export of medical products imposed in response to COVID-19, as of 28 April 2020

\begin{tabular}{|c|c|c|c|}
\hline Country or grouping & Type of measure & $\begin{array}{l}\text { Date of entry } \\
\text { into force }\end{array}$ & Duration \\
\hline \multicolumn{4}{|l|}{ Extraregional } \\
\hline Switzerland & $\begin{array}{l}\text { Authorization is required for the export of personal protective } \\
\text { equipment, except to the European Union, the United Kingdom } \\
\text { and the European Free Trade Association }\end{array}$ & 26 March 2020 & Not stated \\
\hline India & $\begin{array}{l}\text { The export of masks, other personal protective equipment, } \\
\text { mechanical ventilators, test kits and disinfectants is banned }\end{array}$ & $\begin{array}{l}\text { Between } 25 \text { February } \\
\text { and } 4 \text { April } 2020\end{array}$ & Indefinite \\
\hline Brazil & $\begin{array}{l}\text { A special licence is required to export masks, other personal } \\
\text { protective equipment, mechanical ventilators, disinfectants } \\
\text { and test kits, among others }\end{array}$ & 18 March 2020 & Not stated \\
\hline Colombia & $\begin{array}{l}\text { Exports are banned of masks and certain personal protective } \\
\text { equipment, disinfectants, certain medications, mechanical } \\
\text { ventilators and other medical equipment }\end{array}$ & 22 March 2020 & Six months \\
\hline Costa Rica & $\begin{array}{l}\text { An export licence is required for masks and other personal } \\
\text { protective equipment }\end{array}$ & 10 April 2020 & $\begin{array}{l}\text { For the duration of the } \\
\text { public health emergency }\end{array}$ \\
\hline
\end{tabular}

Source: Economic Commission for Latin America and the Caribbean (ECLAC), on the basis of World Customs Organization (WCO), "List of national legislation* of countries that adopted temporary export restrictions on certain categories of critical medical supplies in response to COVID-19" [online] http://www.wcoomd.org/en/topics/facilitation/activities-and-programmes/natural-disaster/list-of-countries-COVID-19.aspx, and World Trade Organization (WTO), "Annex COVID-19 Trade and trade-related measures (As of 4 May 2020)" [online] https://www.wto.org/english/ tratop_e/covid19_e/covid_measures_e.pdf.

The United States and India have introduced tighter measures. India has banned the export of an extensive list of items, including personal protective equipment, mechanical ventilators and test kits, among others. ${ }^{4}$ The Government of the United States has established that certain products cannot be exported as a general rule, because the local demand exceeds supply. Specifically, it has been decreed that surgical masks, N95 respirators and similar devices, and surgical gloves may only be exported with the approval of the Federal Emergency Management Agency (FEMA), and has indicated that other products may be added to that list as the pandemic evolves. In practice, the measure will likely have a similar impact to an outright ban on exports.

4 Export restrictions on several medicines were lifted on 6 April 2020 
Two criteria were used to determine the products where the region's supply is most compromised as a result of currently known restrictions:

(i) That registered imports of the product amounted to US\$ 100 million or more in 2018 ( $0.33 \%$ of the region's total imports of the set of medical products analysed in this document)

(ii) That the group of countries having restricted exports of a product represent more than $20 \%$ of the value of regional imports of that product in 2018 . Although the United States has officially introduced restrictions on a limited number of products thus far, for illustrative purposes all medical products where the United States accounted for at least $20 \%$ of regional imports by value in 2018 have been included in the analysis

A list of 22 products whose regional supply is currently most at risk was drawn up on the basis of the above analysis (see annex table A1). In all cases, the main source of vulnerability is the heavy dependence on imports from the United States, which exceeds $30 \%$ for 14 products and $50 \%$ for 6 products.

The region's vulnerability is of particular concern with respect to N95 respirators and similar devices, which are critical for the protection of health professionals directly exposed to coronavirus. In 2018, 58\% of imports of these respirators, by value, came from the United States, which has banned their export since the beginning of April. This is in addition to $18 \%$ of respirator imports coming from Germany, Poland and the United Kingdom, which are subject to the transitional regime introduced by the European Union in March, under which authorization is required to export respirators outside the bloc. This means that over $75 \%$ of regional imports of this product are currently subject to some kind of restriction.

In the case of disposable surgical masks, 30\% of the region's imports by value in 2018 came from the United States, which has practically prohibited their export. However, the main regional supplier of this product is China, with a $50 \%$ share. China has not placed any kind of restriction on the export of medical products and, in fact, is sharply increasing its shipments of masks, ventilators and other products necessary to combat COVID-19.

In the case of mechanical ventilators, the main supplier to the region is again the United States, which accounted for one third of total imports in 2018. Although this product has not so far been included in the legislation adopted by the United States concerning export restrictions, de facto restrictions have been reported and formal export restrictions may likely follow amid the worsening health crisis. Conversely, none of the region's suppliers of mechanical ventilators other than the United States has adopted export restrictions.

\section{Conclusions and preliminary recommendations}

In his letter dated 23 March 2020 to the leaders of the Group of Twenty (G-20), the Secretary-General of the United Nations, António Guterres, urged them to remove trade restrictions, including tariffs, quotas and non-tariff measures, that affect the deployment of medical equipment, medicines and other essential goods to fight COVID-19. At the extraordinary virtual summit held on 26 March 2020, the G-20 leaders pledged that their emergency trade measures would be targeted, proportionate, transparent, and temporary. However, there has since been a steady increase in formal and informal export restrictions.

As the major powers compete openly for supplies such as masks and mechanical ventilators, it is the developing regions that are most adversely affected. Resolution 74/274 adopted by the General Assembly on 20 April 2020 is thus a milestone. It stems from an initiative of the Government of Mexico to ensure global access to medicines, vaccines and medical equipment to face COVID-19. The draft resolution, presented by Mexico, was co-sponsored by 179 countries in a clear reflection of the gravity of the situation. 
The COVID-19 pandemic has brought to the fore the region's heavy dependence on imports from outside Latin America and the Caribbean. In recent weeks, at least 12 Latin American and Caribbean countries ${ }^{5}$ have temporarily reduced or even removed import tariffs on medical products and have eased administrative and regulatory requirements. The effectiveness of these measures is greatly reduced, however, if at the same time many of the main suppliers are restricting their exports.

There are major suppliers of all the products in question who have not yet applied export restrictions and to whom the countries of the region could turn to offset current or potential shortages in supply from the United States, the European Union and India. China, in particular, and other countries such as Japan and the Republic of Korea are some examples. However, growing demand for medical supplies and equipment has prompted the United States and a number of European countries to increase purchases from China. International media reports indicate that this competition is driving up prices, leaving the region at a disadvantage vis-à-vis advanced countries. Against this backdrop, the collective procurement of medicines and other supplies by a group of countries is an attractive option for negotiating better conditions on international markets.

In the current complex situation, many countries in the region have mobilized their production capabilities to meet the demand for supplies and products that cannot be met through imports. Some automotive companies have temporarily redirected manufacturing operations towards the production of mechanical ventilators, and some textile and clothing companies are doing the same to produce masks. Universities and research centres in many countries have also joined in the effort. This should help to mitigate the negative impact that export restrictions are already having on public health in the region. Similarly, those Latin American countries that have deemed it necessary to temporarily restrict exports of medical and health products should seek ways to reduce any negative impacts on other countries in the region. A possible example to emulate is the export authorization scheme for personal protective equipment implemented in the European Union, applicable only to exports outside the Union.

In the medium term, the region should make it a strategic objective to strengthen its production capabilities in the pharmaceutical and medical supplies and equipment industries. The valuable efforts already being made to this end in a number of countries must be sustained beyond the current health crisis. The public sector, business and academia must pool their efforts in what the renowned Italian economist, Mariana Mazzucato, has termed a mission-oriented industrial policy. ${ }^{6}$ Regional integration will have to play a key role to complement the requisite national efforts. An integrated market of 650 million people would help achieve the scale required to make new and developing industries viable, and to foster shared production and research networks among the various countries and subregions. ${ }^{7}$ The ongoing and painful crisis should therefore be seen as an opportunity to revitalize the integration agenda with a renewed sense of urgency.

Argentina, Brazil, Colombia, Costa Rica, Dominican Republic, Ecuador, El Salvador, Panama, Paraguay, Peru Saint Kitts and Nevis and Uruguay. See World Trade Organization (WTO), "Annex COVID-19 Trade and trade-related measures (As of 14 April 2020)" [online] https://www.wto.org/english/tratop_e/covid19_e/ covid_measures_e.pdf.

6 See M. Mazzucato, "The Entrepreneurial State: Implications for market creation and economic development", XIV Raúl Prebisch Lecture, Santiago, Economic Commission for Latin America and the Caribbean (ECLAC), 19 April 2016 [online] https://www.cepal.org/sites/default/files/events/files/cepal_prebsich_lecture_2016_-mazzucato final.pdf.

7 Economic Commission for Latin America and the Caribbean (ECLAC), "Measuring the impact of COVID-19 with a view to reactivation", Special Report COVID-19, No. 2, 21 April 2020 [online] https://www.cepal.org/ en/publications/45477-measuring-impact-covid-19-view-reactivation/ 


\section{Annex}

Table A1

Latin America and the Caribbean: medical products most likely to be affected by supply disruptions owing to export restrictions

\begin{tabular}{|c|c|c|c|c|c|c|}
\hline \multirow[b]{2}{*}{ Category } & \multirow{2}{*}{$\begin{array}{l}\text { Code in the } \\
\text { Harmonized } \\
\text { Commodity } \\
\text { Description and } \\
\text { Coding System }\end{array}$} & \multirow[b]{2}{*}{ Short description } & \multirow{2}{*}{$\begin{array}{l}\text { Imports by value } \\
\text { in } 2018\end{array}$} & \multicolumn{3}{|c|}{ Share of imports (2018) } \\
\hline & & & & $\begin{array}{l}\text { United } \\
\text { States }\end{array}$ & $\begin{array}{c}\text { Other main } \\
\text { trading partners } \\
\text { with restrictions }\end{array}$ & China \\
\hline \multirow{5}{*}{$\begin{array}{l}\text { Test kits and } \\
\text { apparatus }\end{array}$} & 3002.10 & Antisera (antibody-positive sera) & 780 & 29.4 & --- & 0.2 \\
\hline & 3002.20 & Vaccines for human medicine & 1382 & 24.9 & 5.7 (India) & 0.0 \\
\hline & 3822.00 & Diagnostic or laboratory reagents & 1387 & 40.5 & --- & 3.8 \\
\hline & 3907.20 & Polyethers in primary forms & 985 & 65.1 & --- & 6.5 \\
\hline & 9027.80 & $\begin{array}{l}\text { Instruments and apparatus for physical } \\
\text { or chemical analysis }\end{array}$ & 576 & 32.4 & --- & 8.5 \\
\hline $\begin{array}{l}\text { Personal } \\
\text { protective } \\
\text { equipment }\end{array}$ & 6210.10 & $\begin{array}{l}\text { Protective garments made up of felt or } \\
\text { nonwovens, whether or not impregnated }\end{array}$ & 173 & 22.7 & $1.2^{\mathrm{a}}$ & 48.3 \\
\hline Thermometers & 9025.19 & Thermometers and pyrometers & 152 & 34.7 & --- & 27.0 \\
\hline \multirow{4}{*}{$\begin{array}{l}\text { Disinfectants } \\
\text { and } \\
\text { sterilization } \\
\text { products }\end{array}$} & 2207.10 & Undenatured ethyl alcohol & 926 & 88.4 & --- & 0.0 \\
\hline & 2847.00 & Hydrogen peroxide & 117 & 27.2 & --- & 0.0 \\
\hline & 3004.90 & $\begin{array}{l}\text { Medicaments consisting of mixed } \\
\text { or unmixed products }\end{array}$ & 9492 & 20.2 & --- & 1.1 \\
\hline & 3808.94 & Disinfectants & 257 & 34.2 & 4.1 (Brazil) & 17.6 \\
\hline \multirow{2}{*}{$\begin{array}{l}\text { Other medical } \\
\text { devices }\end{array}$} & 9018.19 & Electrocardiographs & 515 & 34.6 & 2.1 (India) & 20.8 \\
\hline & 9018.90 & $\begin{array}{l}\text { Medical instruments and apparatus } \\
\text { not elsewhere included }\end{array}$ & 3011 & 58.7 & 1.3 (Costa Rica) & 7.6 \\
\hline $\begin{array}{l}\text { Medical } \\
\text { consumables }\end{array}$ & 9018.39 & Needles, catheters, cannulae and the like & 1533 & 59.2 & --- & 6.3 \\
\hline
\end{tabular}

Source: Economic Commission for Latin America and the Caribbean (ECLAC), on the basis of UN Comtrade-International Trade Statistics Database. Note: Products on which the United States has imposed official export restrictions are shown in a darker shade.

a Spain, Paraguay and Romania.

${ }^{\mathrm{b}}$ Includes disposable masks.

c Brazil, Colombia, India and Vietnam.

${ }^{d}$ Includes N95 and similar respirators.

e Germany, Poland and the United Kingdom.

${ }^{\mathrm{f}}$ Includes mechanical ventilators. 
This document is part of a series of reports prepared by the Economic Commission for Latin America and the Caribbean (ECLAC) on the evolution and effects of the COVID-19 pandemic in Latin America and the Caribbean. It was prepared by the Division of International Trade and Integration, directed by Mario Cimoli, under the general coordination of Alicia Bárcena, Executive Secretary of ECLAC.

Copyright (C) United Nations, 2020 